Jurnal Widya Sastra Pendidikan Agama Hindu, Vol 4, No. 1, 2021

ISSN: 2656-7466

\title{
LONTAR YAMA PURWANA TATTWA
}

\author{
Dra. Ni Wayan Seriasih, M.Hum \\ Seriasih59wayan@gmail.com
}

\begin{abstract}
ABSTRAK
Lontar Yama Purwana Tattwa adalah Salah satu lontar atau naskah tradisional Bali yang bernafaskan siwaistik yang memuat tentang tuntunan upacara pitra yadnya baik dari upacara, upakara dan sarana bade atau petulangan yang di gunakan dalam upacara ngaben. Naskah aslinya memakai aksara Bali dan telah dilakukan alih aksara serta alih bahasa ke dalam huruf latin. Telah pula diterjemahkan ke dalam bahasa Indonesia oleh tim penterjemah, yang tujuannya adalah guna memudahkan memahami isi yang terkandung di dalam naskah tersebut. Keseluruhan naskah ini (lazimnya dikenal oleh masyarakat Hindu di Bali adalah lontar) terdiri atas 16 lembar atau helai daun lontar (siwalan).

Dalam lontar Yama Purwana Tatwa ini tertulis bentuk dan jenis petulangan dalam upacara ngaben ada yang di sebut petulangan lembu, macan, singa, singa kaang, naga kaang, gedarba, gajah mina dan sudang-sudangan. Berdasarkan uraian di atas dapat disimpulkan bahwa jenis, warna atau bentuk-bentuk petulangan sebagai berikut.
\end{abstract}

1. Petulangan lembu warna putih, dan lembu hitam idealnya binatang lembu dipakai oleh orang yang dipandang suci seperti para pendeta, para pemangku (lembu, putih) dan lembu hitam oleh kesatria dan brahmana welaka.

2. Bentuk petulangan singa, bentuknya idealis singa, (yang disebut Singa Ambara Raja) warnanya merah tua bersayap. Umumnya dipakai oleh raja-raja dan warga tangkas koriagung.

3. Petulangan bentuk naga kaang, ialah bentuk idealis naga dikombinasikan dengan ikan, berkepala naga dan badan bersisik ikan dan bersayap. Kaki sebagai kaki lembu dan bersisik pada bagian belakang kaki, dipakai oleh para arya sentong, sekte wisnu.

4. Bentuk petulangan gedarba idealnya binatang beruang, berwarna hitam. Kaki bertanduk (tegil), dipakai oleh kula wangsa (orang kebanyakan).

5. Bentuk petulangan gajah mina idealnya kombinasi dari binatang gajah dan ikan berupa binatang purba sejenis ikan berkepala gajah, dipakai oleh golongan wesia.

6. Bentuk petulangan singa kaang, berbentuk singa, kaki bagian belakang bertanduk dan bersisik seperti sisik ikan dipakai oleh pasek Bali aga dan pasek pulasari.

7. Bentuk petulangan menjangan, idealnya binatang menjangan bertanduk bercabang-cabang, dipakai oleh sang arya 
8. Bentuk petulangan macan (harimau), idealnya binatang harimau, warna merah dan kulit belang, dipakai oleh, pande (keturunan dari seorang Maha Mpu Brahma Raja Wisesa;"babad pande").

9. Bentuk petulangan sudang-sudangan, berbentuk seperti ikan dan kulit bersisik, dipakai oleh para nelayan di daerah tepi pantai.

10. Bentuk petulangan tabla, berbentuk peti biasa, berkaki empat sebagai penyangga. Warnanya putih simbul kesucian, dipakai oleh mereka yang dipandang suci.

Kemudian di dalam lontar Yama Purwana Tatwa dijelaskan beberapa hal diantaranya sebagai tuntunan upacara yadnya di Bali seperti halnya :

- Upacara Nyekah untuk para roh leluhur agar nantinya juga dapat mengakibatkan Jiwatman mengalami proses reinkarnasi berulangulang di dunia ini. Dan mngalami proses peningkatan sang roh menuju alam yang lebih baik, supaya tidak terjebak di alam astral dan bisa menuju alam hyang yama dipati untuk mengalami proses pengadilan.

- Selain itu lontar Yama Purwana Tatwa juga Salah satu lontar kamoksan yang memiliki perhitungan hari, wuku dan sasih (wariga) yang khusus mengatur dalam pencarian ala ayuning dewasa, untuk dapat melaksanakan upacara khususnya pitra yadnya baikitu ngaben, nyekah, memukur, maligia dan lain sebagainya.

Lontar Yama Purwana Tatwa tidak hanya satu-satunya lontar yang mengatur tentang pitra yadnya namun di dukung juga dengan beberpa lontar lainya yang sama-sama memuat tentang tuntunan pelaksanaan upacara pitra yadnya adapun beberapa lontar yang mendukung upacara pengabenan di antaranya lontar yama tatwa, lontar dharma sunia, lontar pratekaning atma wong pejah dan lontar Weda puja pitra siwa.

Hindu Bali dengan taat selalu menjalankan tradisi yang di wariskan, deangan cara catur dresta yaitu empat cara atau kebiasaan untuk melakukan suatu yadnya, baik itu dengan cara desa dresta yaitu kebiasaan pada suatu desa, kune dresta yaitu kebiasan yang dilakukan berdasarkan turun temurun, kula dresta yaitu kebiasaan yang dilakukan dalam suatu keluarga dan juga sastra destra yaitu kebiasaan yang dilakukan berpedoman dengan sastra-sastra yang ada baik itru Weda, purwana, babad, lontar, tatwa dan lain sebagainya. Jadi ke empat kebiasan ini sering disebut dengan desa mawacara atau desa kalapatra. Masyarakat Hindu Bali meskipun ada perbedaan- perbedaan pelaksanaan upacara yadnya namun pada esensinya memiliki tujuan yang sama. Salah satunya adalah upacara ngaben, Di Bali banyak kita lihat perbedaanperbedaan dalam upacara panca yadnya, baik dari segi reringitan atau bentuk banten, sarana upacara dan upakara pun berbeda. Apalagi jika di lihat pada upacara pitra yadnya khusunya pengabenan banyak kita lihat perbedaan- perbedaan baik dalam penggunaan wadah atau bade dan petulangan hal ini terjadi karna desa mawacara dan juga bhisama yang di sesuaikan dengan klen atau soroh sang yajamana. Namun apapun 
perbedaan itu pada hakekatnya memiliki tujuan yang sama dan tidak menyimpang dari Weda sebab lontar adalah pengejawantah dari pada Weda.

Umat Hindu khususnya yang ada di Bali yang telah meninggal dunia harus dikembalikan terlebih dahulu jazadnya menuju alam semesta. Baik itu di kubur atau dibakar. Sebagian besar masyarakat Hindu Bali melakukan upacara pengabenan ini adalah dengan membakar. Inti dari upacara ngaben adalah pralina, baik itu pralina menggunakan api sekala atau niskala yaitu mantra puja gni pralina. Pralina itu telah memberikan makna bahwa jazad manusia itu telah kembali menuju alam semesta. Yaitu menyatunya Panca Mahabutha Bhuana Alit dan Panca Maha Butha Bhuana Agung. Pengembalian jazad ini dipandang perlu karena baik manusia maupun alam semesta dipandang terkomposisi dari unsur-unsur yang sama, yaitu zat cair, zat padat, panas, angin, dan unsur halus yang disebut dengan unsur Panca Maha Butha. Upacara pengabenan merupakan upacara simbolis yang bertujuan untuk melebur manusia, jasad kasar manusia yang disebut dengan Panca Maha Butha Alit, menuju alam semesta, atau yang disebut dengan Panca Maha Butha Agung. Melalui ngaben inilah, dalam pandangan kepercayaan masyarakat Hindu di Bali umumnya, jazad manusia tersebut mampu lebur kemBali menuju makrokosmos, atau alam semesta (Panca Maha Bhuta Agung tersebut). Logika umum mengatakan bahwa melalui ngaben ini manusia dibakar. Dengan dibakar, jazad tersebut dipandang melebur menjadi angin, api, air, tanah, dan menuju luar angkasa yang hampa udara. Baik alam semesta (Panca Maha Butha Agung atau makrokosmos) maupun Panca Maha Butha Alit (Manusia, dan mahluk hidup pada umumnya), mempunyai karakter yang sama, yakni zat padat, zat cair, angin, panas, dan unsur yang halus seperti ruang hampa udara. Pada manusia, ruang hampa yang sangat halus ini disebut-sebut ada pada rambut dan kuku. Dengan pemahaman seperti ini, yaitu peleburan antara badan kasar yang ada pada manusia menuju unsur-unsur yang ada di alam semesta itu, maka ditafsirkan cara yang paling cepat untuk melakukan hal itu, dengan membakar jenazah. Melalui pembakaran itulah seluruh badan kasar manusia akan tercepat bersatu dengan alam semesta. Setelah jenazah tersebut menjadi abu, maka setelah diadakan upacara tertentu, abunya segera dibawa menuju sungai atau ke laut untuk dilarung. Maka secara sederhana ditafsirkan dalam kepercayaan anggota masyarakat, pembakaran tersebut menghasilkan debu dan asap, yang semuanya bisa membawa bergabungnya jazad tersebut bergabung menuju tanah dan angkasa sedangkan abu yang dibuang ke laut atau ke sungai, akan segera bergabung dengan air dan jika menguap, akan bergabung dengan angkasa, angin dan sebegainya. Jadi, telah bergabung dengan Panca Maha Butha Agung, atau alam semesta.

Manusia terdiri dari dua unsur, yaitu jasmani dan rohani. Menurut agama Hindu, manusia itu terdiri dari tiga lapis, yaitu raga sarira, suksma sarira, dan antahkarana sarira. Raga sarira adalah badan kasar, badan yang dilahirkan karena nafsu (ragha) antara ibu dan bapak. Suksma sarira 
adalah badan astral atau badan halus yang terdiri dari alam pikiran, perasaan, keinginan dan nafsu (citta, manah, indria, dan ahamkara). Antahkarana sarira adalah yang menyebabkan hidup atau Sang Hyang Atma. Ragha Sarira atau badan kasar manusia terdiri dari unsur Panca Maha Butha, yaitu pratiwi, yang merupakan unsur tanah yang di dalam badan manusia disimbolkan dengan zat padat; apah, adalah zat cair, yang di dalam tubuh manusia diperlihatkan oleh zat cair seperti darah, kelenjar dan lainnya; teja adalah api atau panas yang di dalam tubuh manusia diperlihatkan oleh suhu badan; bayu adalah angin, yang di dalam tubuh manusia diperlihatkan oleh adanya nafas; dan terakhir adalah akasa atau ether, yakni unsur badan yang terhalus yang di dalam tubuh manusia diperlihatkan oleh rambut dan kuku. Proses terjadinya Ragha Sarira adalah sebagai berikut. Sari-sari Panca Maha Butha yang terdapat pada berbagai jenis makanan terdiri dari enam rasa yang disebut dengan sad rasa, yaitu, madhura (manis), amla (asam), tikta (pahit), kothuka (pedas), ksaya (sepat), dan lawana (asin). Sad rasa tersebut dimakan maupun diminum oleh manusia, lakilaki maupun perempuan. Dalam tubuh diproses, disamping menjadi tenaga, ia menjadi kama. Kama Bang (sel telur wanita) dan kama putih (sperma laki-laki). Dalam persenggamaan dua kama ini akan bergabung dan bercampur melalui pengentalan dan menjadilah janin, badan bayi ( kama reka) dalam lontar Agastya prana. Sisanya menjadi air nyom, darah, lamas (kakere) dan ariari. Percampuran kedua kama ini dapat menjadi janin, bilamana atma masuk atau turun ke dalamnya. Konon atma ini masuk ke dalam unsur kama yang bercampur ini pada saat bapak dan ibu dalam keadaan lupa, dalam asyiknya menikmati rasa.

Disamping Panca Maha Butha yang kemudian berubah menjadi janin, ikut juga Panca Tan Matra, yakni benih halus dari Panca Maha Butha. Panca Tan Matra ini dalam janin bayi juga memproses dirinya menjadi Suksma Sarira (citta, manah, indria, ahamkara). Citta terdiri dari tiga unsur yaitu Tri Guna yang terdiri dari satwam, rajas, tamas. Ketiga unsur ini membentuk akhlak manusia. Manah adalah alam pikiran dan perasaan, indria adalah alam keinginan, dan ahamkara adalah alam keakuan. Alam transparan ini dapat merekam dan menampung hasil-hasil yang dikerjakan oleh badan atas pengendali citta tadi. Bekas-bekas ini nantinya merupakan muatan atma yang akan pergi ke alam pitara. Ketika manusia itu meninggal, Suksma Sarira dan atma akan pergi meninggalkan badan kasar. Atma yang sudah begitu lama menyatu dengan Sarira, atas kungkungan Suksma Sarira, sulit sekali meninggalkan badan itu. Padahal badan sudah tidak dapat difungsikan lagi, karena bagian-bagiannya sudah rusak. Hal ini merupakan penderitaan bagi atma. Agar tidak terlalu lama atma terhalang perginya, perlu badan kasarnya diupacarakan untuk mempercepat proses kemBalinya menuju sumbernya di alam, yakni Panca Maha Butha (Agung). Proses inilah yang disebut dengan ngaben .

Dalam runtutan upacara ngaben yang terdapat dalam lontar yama purwana tatwa ada yang disebut dengan memukur. Memukur merupakan upacara tahap kedua dari Pitra Yadnya, yaitu mengemBalikan jazad 
manusia yang telah bergabung dengan alam semesta tersebut menuju alam pitara, yakni alam yang berdekatan dengan Tuhan.Upacara ngaben di yakini sebagai ritual untuk mengemBalikan unsur panca mahabutha, dari badan manusia atau bhuana alit kedalam alam semesta atau bhuana agung. Dan pada nantinya akan menuju kepada tujuan hidup agama Hindu yaitu menyatunya atma dengan brahman.

Gejolak dinamisasi masyarakat Bali setiap hari selalu mengalami suatu perubahan salah satunya pada upacara panca yadnya yang tanpa kita sadari banyak terjadi suatu perubahan- perubahan baik ke arah yang lebih baik atau malah seBaliknya, apalagi di era pandemic seperti saat ini banyak terjadi pergeseran suatu budaya yang sudah kita warisi, mau tidak mau harus tunduk dengan atauran dan hukum alam yang sedang bekerja, contohnya dulu sebelum ada pandemi setiap upacara yadnya yang ada di Bali selalu di padati oleh peserta, dan melibatkan banyak tenaga dan biaya untuk menopang suatu yadnya sehingga bisa berjalan dengan lancar. Namun coba kita lihat sekarang di era pandemic saat ini dengan di kluarkanya perda dari gubenur dan Majelis Desa Adat setiap upacara di batasi peserta atau jumlah yang terlibat, hal ini tanpa kita sadari membuat banyak pergeseran dalam tatanan budaya, contohnya gambelan tidak lagi digunakan untuk sementara waktu, namun hal ini tidak mengurangi esensi dari pelaksanaan yadnya tersebut karna inti dari tujuan setiap yadnya bisa di capai. Sekarang kita contohkan upacara ngaben sebelum pandemi sangat banyak mengunakan waktu baik persiapan, atau mengundang kerabat dan sanak saudara, membutuhkan tenaga dan biaya yang banyak, namun sekarang karna peraturan yang ada banyak masyarakat yang memilih melakukan upacara pengabenan di yayasan kremasi. Karna masyarakat menilai disana sudah ada team atau anggota yayasan yang siap embantu dan mnyiapkan segala sarana prasarana untuk mendukung berlangsungnya upacara tersebut. Salah satunya di yayasan pengayom umat Hindu atau YPUH, singaraja. Yang sudah pasti tetap mengacu pada sastra yang ada baik Weda dan juga lontar- Iontar nusantara salah satunya lontar yama purwana tatwa.

Sistem religi yang dulu di dominasi oleh griya sekarang seiring berjalanya waktu dan perubahan jaman tidak lagi di rasakan, bahkan sekarang masyarakat sudah bisa melaksanakan yadnya sendiri baik itu belajar lewat pasraman -pasraman yang ada atau memanfaatkan kecanggihan tekmologi dengan belajar di sosial media dan juga melakukan di yayasan- yaysan Hindu lainya. Sekarang masyarakat lebih dewasa dan sadar tentang apa itu panca sradha, dan masyarakat juga lebih mengerti tentang Tri Kerangka dasar Agama Hindu yaitu Tatwa Etika dan Upakara. Yang sudah pasti tetap mengacu pada sumber-sumber sastra yang ada.

Dalam pelaksanaan Panca yadnya khusunya pitra yadnya sangat diperlukan tindakan yang cepat dan tepat tanpa keluar dari aturan-aturan agama. Maka dari itu penulis merasa berkepentingan untuk mengkaji naskah lontar yama purwana tatwa sebagai tindakan nyata agar 
sebagaian warga bisa berpedoman pada lontar yama purwana tatwa, disaat melakukan upacara pitra yadnya khususnya pengabenan.

Bagi umat Hindu, upacara kematian lebih dikenal dengan istilah pitra yadnya. Pitra yadnya merupakan salah satu bagian dari tri rna yang wajib dilaksanakan oleh umat Hindu agar dapat mencapai kebahagiaan di dunia dan di akhirat, demikian penjelasan Bhagawan Wararuci dalam kitab Sarasamuccaya. Pitra yadnya berasal dari dua kata yaitu pitra dan yadnya. Secara harfiah kata Pitra berati orang tua (ayah dan ibu), dan dalam pengertian lebih luas berarti leluhur. Sedangkan kata yadnya berarti pemujaan, persembahan atau korban suci baik material maupun non material berdasarkan hati yang tulus ikhlas, dan suci murni demi untuk tujuan-tujuan yang mulia dan luhur. Yadnya pada hakikatnya bertujuan untuk membebaskan manusia dari ikatan dosa, dan ikatan karma, untuk selanjutnya dapat menuju pada "Kelepasan". Dengan demikian pitra yadnya berarti pengorbanan suci yang dilandasi oleh rasa hati yang tulus ikhlas yang ditujukan kepada para leluhur dalam usaha untuk membebaskan arwah para leluhur dari ikatan dosa sehingga berhasil memperoleh kelepasan. Melalui penjelasan di atas dapat dipahami bahwa pelaksanaan upacara pitra yadnya mempunyai fungsi yang sangat penting yakni dapat mengantarkan seseorang untuk memperoleh kebahagiaan di dunia dan di akhirat, selanjutnya dapat mengantar arwah leluhur untuk memperoleh kelepasan atau moksa

Dalam perkembangan masyarakat Hindu Bali saat ini, pemikiran demikian juga masih ada. Misalnya, jika ada seseorang yang memiliki anggota keluarga belum diaben, mereka percaya akan mendapat kesakitan atau masalah-masalah lainnya di dalam keluarga. Karena itulah ngaben tetap menjadi perhatian penting untuk dilaksanakan dalam masyarakat Hindu Bali. Dengan demikian, adanya Rna atau kewajiban untuk membayar utang kepada leluhur, yang kemudian bersinggungan dengan kewajiban melaksanakan korban suci yang berupa yadnya kepada Pitra (leluhur), akhirnya bergabung dengan ketakutan-ketakutan, baik yang telah tersurat dalam lontar maupun yang ditegaskan lagi oleh para pendeta, membuat upacara ngaben ini akhirnya mirip menjadi sebuah keharusan bagi umat Hindu di Bali. Pada umat Hindu lain di Indonesia, tidak ada upacara yang disebut dengan ngaben, kecuali terhadap umat Hindu transmigran yang memang berasal dari Pulau Bali, Ngaben di Bali, dengan demikian merupakan sebuah ritual budaya yang dalam pelaksanaannya, sangat dikaitkan dengan ritual keagamaan Hindu Bali.

Teks Yama Purwana Tattwa menempatkan pelaksanaan upacara kematian sebagai sesuatu yang sangat gaib, sakral dan religius, seperti dijelaskan pada bait di bawah ini:

"Nihan daging kcap Yama Purwana Tattwa, par ssi, tingkah angupakara sawa sang mati, agung alit, nistha madhia utama, maka patuting wulah sang magama tirtha ring Balirajia, kewala wwang mati bner tan wnang 
Jurnal Widya Sastra Pendidikan Agama Hindu, Vol 4, No. 1, 2021

ISSN: 2656-7466

mapendem, mangde magseng juga, saika supacarania, prasida Sang Atma molih ring Bhatara Brahma".

Terjemahan:

Inilah isi dari Yama Purwana Tattwa tersebut; Bila melakukan upacara kematian sesuai dengan kemampuan yang disebut sederhana, menengah dan Utama (nistha, madhya, uttama). Agar tidak menyimpang dari petunjuk bagi umat yang beragama Hindu di pulau Bali. Hanya orang yang mati secara wajar tidak boleh dikuburkan, agar dibakar saja, disertai dengan upacara supaya roh orang tersebut mendapat tempat disisi Dewa Brahma (Yama Purvana Tattwa, 2b).

Teks di atas menjelaskan betapa pentingnya melaksanakan upacara kematian terhadap para leluhur, mengingat dengan cara demikian para leluhur akan berhasil memperoleh tempat disisi Dewa Brahma (Ida Sang Hyang Widhi dalam manifestasinya sebagai pencipta). Melalui sloka di atas, dapat dipahami bahwa upacara kematian memiliki fungsi yang sangat penting, yakni sebagai petunjuk jalan serta penuntun arwah leluhur sehingga mereka bisa tiba disisi Dewa Brahma.

Teks di atas juga menegaskan bahwa, bila menyelenggarakan upacara kematian hendaknya jangan memaksakan diri untuk melakukan upacara yang besar, akan tetapi harus disesuaikan dengan kemampuan keluarga yang ditinggalkan sehingga tidak menjadi beban. Walau melaksanakan upacara kematian yang sangat sederhana, tanpa harus mengeluarkan banyak biaya, asal dapat segera dilaksanakan dan dilandasi oleh hati yang tulus ikhlas maka arwah leluhur akan memperoleh kebahagiaan yang abadi di sisi Dewa Brahma.

Sehubungan dengan itu swarga rohana parwa Jawa kuno, memberikan penjelasan dan pemahaman tentang swarga atau neraka sebagai berikut: ketika Yudistira, raja yang sangat bijaksana sampai di swarga, dia menyaksikan sepupunya para Korawa menikmati kehidupan yang sangat menyenangkan, apapun yang diinginkan tersedia disana, dilayani oleh banyak bidadari yang cantik-cantik, sehingga mereka sangat berbahagia. Yudistira sangat sedih, karena adik-adik beserta istrinya tidak ada disana, mereka sedang menerima hukuman di neraka. Keadaan itu menyebabkan Yudistira bersikeras tidak mau tinggal di svarga, ia memilih berkumpul dengan adik-adik dan istrinya walau di neraka. Kemudian Dewa Sudata mengantarnya sampai di Yamaniloka, tempat yang sangat mengerikan. Disana ia mendapatkan adik-adik dan istrinya direndam pada air kawah yang sangat panas, dipenuhi oleh belatung, cacing, ulat dan sebagainya, sungguh sangat menakutkan. Itulah hukuman atas perbuatan buruknya pada kehidupan yang lalu. Akan tetapi begitu Yudistira menginjakkan kakinya di neraka, seketika neraka itu menjadi sejuk, sehingga semua roh memohon agar Yudistira tetap tinggal di sana guna memberi pertolongan. Mereka merasakan kesejukan seperti diperciki air suci. Yudistira tidak berkenan meninggalkan tempat itu, dan tidak lama 
kemudian para Dewata berdatangan, dan tempat itupun berubah menjadi svarga yang indah dan memberikan kebahagiaan kepada Para Pandawa dan Dewi Drupadi .

Melalui ilustrasi ceritera di atas, dapat dipahami bahwa semua karma membawa pahala, ada aksi - ada reaksi. Diminta ataupun tidak setiap karma pasti menghasilkan pahala. Pandawa yang dalam kehidupannya lebih cenderung pada subha karma, juga menikmati neraka walau hanya sebentar, karena pada hakikatnya tidak ada manusia yang sempurna. Setelah karma buruknya dinikmati kemudian ia memperoleh kebahagiaan yang abadi. Sedangkan Korawa yang lebih cenderung pada asubha karma, menikmati swarga walau hanya sebentar, karena pada hakikatnya setiap orang pasti ada sisi baiknya, untuk selanjutnya ia menerima pahala buruknya di neraka. Swarga atau neraka bukanlah hadiah atau hukuman akan tetapi merupakan pilihan kemana kita mau melangkah. Apapun kecendrungan yang dilakukan seseorang semasa hidupnya, maka itu pulalah yang akan dia nikmati.

Sejalan dengan itu Weda Puja Pitra Siwa menjelaskan bahwa semua bentuk upacara kematian berfungsi sebagai penyucian dan pengantar arwah leluhur sampai di ayathana sthana (wilayah perbatasan antara svarga dan neraka) selanjutnya neraka atau svarga yang dicapai karmawasananyalah yang menentukan.

Adapun isi yang terkandung dalam naskah lontar Yama Purwana Tattwa akan penulis coba paparkan secara sederhana, yang harapannya adalah dapat disimak maknanya, baik secara filosofis, teologis, maupun ritual

\section{Secara filosofis,}

Secara filosofi bahwa ada beberapa sarana utama yang dipakai dalam, upacara kematian sesuai naskah Yama Purwwa Tattwa, di antaranya: pisang jati sebagai warna, asep sebagai mata, nasi angkeb sebagai mulut, bubur pirata sebagai suara, dukut lepas sebagai dubur, cawan sebagai dahi, daun kayu sugih sebagai hidung, kusa sebagai bulu mata, jawa sebagai alis, pili-pili sebagai ulu hati, panjang Uang sebagai lidah, ending sebagai bibir, don rotan sebagai punggung, asep sebagai gusi, pengawak sebagai tulang belakang, tebu sebagai lengan, cendana sebagai tulang kelingking, rempah-rempah sebagai inti atau sebagai atma. Panyugjug sebagai jalan, panyugjug mameri sebagai penuntun yang paling depan, baju (wastra) sebagai kulit, kain wangsul sebagai telapak kaki, topi sebagai lutut ganjang/ganjaran berisi uang sebagai tulang lutut, sangku sebagai kantung kemih, kipas sebagai nafas, kotak sebagai daging, tiga sampir sebagai urat, dan gagadhing, emba-embanan sebagai kepala.

\section{Secara Teologis}


Secara teologis dinyatakan dalam naskah lontar Yama Purwana Tattwa, bahwa upacara kematian yang lazim disebut sebagai upacara ngaben (baik nyawa Wedana, swasta, dan yang sejenis dalam upacara kematian) sesungguhnya ditujukan kehadapan Sang Hyang Siwa (sebagai asal dari semua ciptaan di dunia ini). Sesuai sumber naskah Yama Purwana Tattwa bahwa orang yang meninggal, dikubur di pertiwi, dan dibuatkan upacara pengabenan mendapatkan anugerah dari Sang Hyang Yama dipati guna menghilangkan segala kekotoran (leteh) sehingga roh orang yang meninggal kemBali ke alam Siwa. Adapun nyasa atau simbul dari orang yang meninggal secara teologis digambarkan dengan huruf Triaksara, Omkara, dan aksara Rwa Bhineda yaitu aksara ONG dan ANG $\mathrm{AH}$ yang dilengkapi dengan sesajen yang diperlukan.

Selanjutnya jika roh orang yang meninggal masih dalam keadaan sengsara, kotor (cukil daki atau butha diya diyu) belum layak diupacarai ngentas, oleh karena hal demikian secara teologis mendapatkan kutukan dari Sang Hyang Haricandana (sebutan lain dari Deva Siwa) untuk tinggal di dasar kawah naraka atau cambra gohmuka dan bukan tinggal di alam Siwa. Kutukan Sang Hyang Haricandana dilanjutkan dengan penyerahan kehadapan Dewa Brahma, yang pada akhirnya diserahkan kehadapan kepada Sang Hyang Yamadipati untuk ditempatkan di kawah naraka. Kelak pada saat kelahirannya dinyatakan akan menjelma menjadi berkaki satu, berkaki tiga, dempet, dimpil, darih (mandul), deyog, pirut (kerdil), picek, dingkil, buta, tuli, gudug (jari dan tangan terlepas karena penyakit lepra), basul (perut dan pusar nonjol), beseh (berkali-kali kencing tanpa dirasakan), agong (abong), bulai, gondong, punuk (ponok), segala cacat tubuh dideritanya, demikian keburu-kannya, dunia kacau, bercampur baur, dunia salah perhitungan, hujan tidak sesuai dengan musimnya, ular banyak dan tikus galak merajalela.

\section{* Secara Ritual}

Secara ritual bahwa naskah Yama Purwana Tattwajuga memaparkan bagaimana upacara kematian, khususnya upacara Nyawa Wedanayang upakaranya terdiri atas guling bebangkit selengkapnya, sebagai penebusan, sesajen beralaskan nyiru sebanyak tiga nyiru, tetingkeban satu nyiru, untuk sedahan kawah saru nyiru, nasi garuda satu nyiru, dan ditambah pangalang-alang satu nyiru, dan lagi nasi sri kakili, angel-anggel 22 tanding, tambilung upih 108, cunguh kawu 40, berisi nasi setengah matang, yang tiga berisi lauk kulit siput air, dan lagi yang tiga berisi lauk darah, darah bercampur Rabu, dan lagi taksisir, tambling upih besar sebuah, berisi nasi lauk kulit siput air, alang-alang segenggam, darah satu limas berisi ati, bertongkat kayu ha, berisi panca kosika, yang merupakan gabungan dari daksina sebuah, pras lima, nasi putih, nasi merah, nasi kuning, nasi hitam, saji sebuah berisi lauk itik, pelengkap pahumahan lekesan 40 sebesar seperti cane dan lagi ditambah sajen pambuket, tumpeng berpucuk manik, seperti sate panyegjeg sebagai panebasan, berisi nasi setengah matang diolesi cendana, dipancangi orti, pulakerti, dan lagi karas berisi balung, jatu kling, warna, alat-alat kaki patuk, karas berisi alat-alat tukang bangunan. 
Sebagai dasar kawah, kaping berwarna sesuai dengan neptu dan sajen pelengkap berupa galahan (beras 10 catu, telur 10 butir), uang 10 ribu, kelapa 10 butir) ditambah lagi sajen panjang Uang, cacar samah, bubur pirata serta babi seharga 555 yan?; dipotong dibentuk seperti hidup (wingangun urip), daging potongan mentah, urutan angina, pala kiwa, darah 1 piring besar, benang berwarna, bokbokan garuda, benang hitam, benang merah, benang putih, dan lagi gula sakerek, kelapa setengah berisi gula kelapa sebutir, lagi kelapa setengah berisi gabah, botol 2, pelengkap wak-wakan, telor 9 , nasi pulupuhan 1 , nasi pujungan 1 , nasi sokan 1 , tuak 1 klukuh, arak 1 beruk, air 1 brerong, sujang rentet 5 buah, dan uang tatingkeb 225 , uang bebangkit 225 , uang pulagembal 225 , uang sedahan kawah 225, uang garuda 225 , uang kaki patuk 225 , uang pagu 225 , uang pangalang-alang 225 , uang sega dewa 2, berisi kwangen dan kwangen tersebut berisi permata mulia, masing-masing berisi uang 225 , benang 1 gulung, pras penyarikan 5, masing-masing berisi uang 25 . Sesantun membuat sajen panca sanak, nasi dadong patuk 1 kukusan, lauknya ayam gemerot, angkeb 1, caratan trisula, pane padma, payuk cakra. Sesantun nanding panyapa, bila yang utama 1700, yang sedangsedang 700, yang kecil 500 .

Demikian sekilas paparan mengenai kandungan isi dari naskah lontar Yama Purwana Tattwa, yang sesungguhnya sebagai pedoman bagi umat Hindu dalam melaksanakan upacara kematian atau upacara pengabenan. Inti dari naskah Yama Purwana Tattwa sebagaimana telah dijelaskan di atas, yaitu sebagai pedoman untuk melakukan upacara kematian, agar roh yang meninggal dapat menuju ke alam Siva, tidak seBaliknya ke alam naraka. Secara teologis, bahwa naskah ini mengajarkan kepada umat Hindu untuk menghormati dan berbhakti kepada Deva Siwa beserta dengan manifestasi Beliau. Secara ritual, bahwa naskah ini telah memaparkan beberapa peralatan, sadhana, upakara, yang digunakan untuk kelangsungan upacara kematian atau upacara ngaben bagi umat Hindu. Tentu sumber lainnya masih juga ada keterkaitan dengan naskah Yama Puwrana Tattwayang sama-sama memaparkan tentang upacara kematian.

\section{Daftar Pustaka}

Donder, I Ketut, 2007. Kosmologi Hindu. Paramita, Surabaya.

Kajeng, I Nyoman, dkk. 2007. Saramuccaya. Departemen Agama Pusat. Jakarta

Kantor Dokumentasi Budaya Bali, Tim Penyusun. 1997. Teks, alih aksara, dan alih bahasa lontar

$\begin{array}{ll}\text { - } & \text { Yama Purwwa Tattwa } \\ \text { - Yama Purana Tattwa } \\ \text { - Yama Purwana Tattwa } \\ \text { - Yama Tattwa }\end{array}$


Jurnal Widya Sastra Pendidikan Agama Hindu, Vol 4, No. 1, 2021 ISSN: 2656-7466

Parisada Hindu Darma, Tim Penyusun, 1995. Upadesa. Upada Sastra, Denpasar.

Putra, Drs. I.G.AG. dkk, 1998. Wrhaspati Tattwa. Paramita, Surabaya

Pendit, Nyoman, S. 1994. Bhagawad Gita. Hanuman Sakti, Jakarta.

Suhardana, Drs.K.M. 2009. Catur \& Sad Paramita. Paramita, Surabaya.

Yudabakti, I Made, dkk.2007. Filsafat Seni Sakral dalam Kebudayaan Bali.

Paramita, Surabaya.

Triguna, Ida Bagus Gde Yudha, 2011. Strategi Hindu. Pustaka Jurnal Keluarga.

Jakarta 